\title{
Reliability Assessment of Road Network Operation
}

\author{
Maxim Sharov ${ }^{1 *}$, Alexey Levashev ${ }^{1}$, and Alexander Mikhailov ${ }^{1}$ \\ ${ }^{1}$ Irkutsk National Research Technical University, 83 Lermontov str., Irkutsk, 664074, Russia
}

\begin{abstract}
In the frame of the project «Criteria of traffic control quality and effectiveness in Russian Federation» the Transportation Laboratory of ISTU was invoved into elaboration of network performance appraisal. Two alternative congestion measures were considered. The ratio of peak period to free flow travel times was proposed as a test criterion of urban highway network reliability.
\end{abstract}

\section{Introduction}

Within the framework of the project "Development of Scientific-based Proposals on the Russian Federation Traffic Management Quality and Efficiency Assessment System", the research group of IRNITU Transport Laboratory (TL-ISTU) performed the development of a method to assess the reliability of the urban road network functioning. The participation of the TL-ISTU in this research project is caused by the fact that the laboratory is engaged in a wide range of urban transportation planning tasks [1-4,7-11].

\section{Material and methods}

Conciliation and approval of definitions is the first necessary stage of the selection of the criteria to assess the reliability of the urban road network operation process. "Traffic jams" and "traffic congestion" are usually considered as the failure of the URN operation, but they have not been accurately determined and have not been officially accepted definitions yet. A completely different situation is observed in the international practice of transport planning and the traffic management where the term congestion (congestion, traffic congestion) is widely used.

The translation of the term "congestion" is of a certain complexity, since it summarizes the whole set of condition characteristics of the urban road network and urban transport systems. Various formulations of the concept "congestion" are given either in professional publications or in internet sources (for example, http://www.wordiq.com).

The Joint Transport Research Center, established in 2004 by the Organization for Economic Co-operation and Development (OECD) and the European Conference of Ministers of Transport (ECMT), states in its methodical document Managing Urban Traffic

* Corresponding author: transport@istu.edu 
Congestion [7] that there is no generally accepted definition and presents the following wording:

- Situation where demand for road space exceeds supply;

- Congestion is the impedance vehicles impose on each other, due to the speed-flow relationship, in conditions where the use of a transport system approaches its capacity

- Difference between the expected by users quality of the urban road network operation and its real condition.

The most important issue from the point of view of the analysis of transport systems is that there are two absolutely different types of congestion [14-18]:

- Non-recurrent congestion occurs as the result of accidental events (accidents, weather conditions, natural disasters, construction works, etc.);

- Recurrent congestion reoccurs systematically (either at the same time or at the same place of occurrence) in the form of high traffic volumes that reduce the quality of the operation of the city's transport system.

Non-recurrent and recurrent congestions are assessed by different quantitative indicators; differ in their reduction measures and are issues of competence of completely different specialists. In general, the effect of congestion on the transportation systems is assessed by changing of duration of running during peak traffic hours in relation to the duration of running under the conditions of free vehicular flow.

In the modern context, while choosing the quantitative index of congestion, two important conditions must be taken into consideration, i.e. so that the selected assessment criterion can be determined on the basis of:

- Data of geo-information technologies (GLONASS / GPS tracks);

- Traffic simulation data.

Taking into account all the above two alternative indices should be considered to conduct a comparative analysis of a transportation congestion level in the cities of the Russian Federation:

- Traffic Index, proposed and used by Tom Tom (www.tomtom.com);

- Travel Time Index, used in Australia, the United Kingdom and the USA [5-9, 12,13].

Tom Tom company started collecting and analyzing the tracks of users of its equipment in 2007. By 2017, 390 cities in 48 countries have already been surveyed. The transport index, proposed by the company, is defined as the total excess of expenditure of time spent by vehicles per day against expenditure of time that vehicles would experience in the conditions of free vehicular flow.

Received by Tom Tom GPS tracks show the following attributes:

- Date and time of recording a track;

- Coordinates of the start and end points of the track;

- Coordinates of the track points and the time spent in them.

On the ground of received GPS tracks, Tom Tom determines the driving speed for each of the tracks and determines the following information for each of the observed cities:

- General level of congestion (Tranffic Index);

- Date of the highest level of congestion per quarter;

- Annual delay per driver;

- Level of congestion on the main roads of the city;

- Level of congestion on the off-main network streets and roads.

Currently, Tom Tom publishes information on five Russian cities (Table 1) 
Table 1. TomTom Traffic Index values in 2016.

\begin{tabular}{|c|c|c|c|c|c|}
\hline \multirow{2}{*}{ City } & \multicolumn{5}{|c|}{ TomTom Traffic Index (Extra travel time), \% } \\
\cline { 2 - 6 } & $\begin{array}{c}\text { Urban road } \\
\text { network } \\
\text { totally }\end{array}$ & Highways & $\begin{array}{c}\text { Non- } \\
\text { highways }\end{array}$ & $\begin{array}{c}\text { Mornin } \\
\text { g Peak }\end{array}$ & $\begin{array}{c}\text { Evening } \\
\text { Peak }\end{array}$ \\
\hline Moscow & 44 & 58 & 41 & 71 & 94 \\
\hline Saint Petersburg & 41 & 20 & 43 & 65 & 90 \\
\hline Nizhny Novgorod & 32 & 23 & 35 & 51 & 59 \\
\hline Ekaterinburg & 34 & 35 & 34 & 56 & 68 \\
\hline Novosibirsk & 35 & 7 & 35 & 53 & 70 \\
\hline
\end{tabular}

\section{Theory}

The example above demonstrates the possibilities of geoinformation technologies to conduct analysis of the reliability of the operation of urban transport systems in our country. Since the Russian Federation does not systematically collect and analyze GLONASS / GPS tracks, it seems reasonable to use the Travel Time Index that is simpler from the point of view of surveys and calculations [1,2].

The Travel Time Index -TTI is determined by the ratio of the travel time during peak hours to the travel time during free-flow or posted speed limit conditions.

$$
T T I=\frac{T_{P}}{T_{F F}},
$$

where $T_{P}$ is travel time during peak hours (min);

$T_{F F}$ - travel time in case of free flow travel speed which is calculated as the $15^{\text {th }}$ percentile travel speed (min).

According to North American transport practice, TTI is considered as one of the most important indicators characterizing the influence of congestion on the quality of the operation of the urban transport system. Annually, statistics data concerning all major cities is collected and summarized, and comparative analysis is conducted in special FHWA's Congestion Dashboard Reports. So, according to the data presented at the site http://d2dt15nnlpfr0r.cloudfront.net in 2011, TTI in cities with a population of over 300 thousand inhabitants varied in the range from 1.36 (Honolulu) to 1.04 (Corpus Christi, Texas).

In general, the following GPS tracks can be sources of data to estimate TTI time index:

- Probe Vehicles (the method of "mobile observer" - floating car);

- Rolling stock of public passenger transport and taxi;

- Volunteer drivers who provide their tracks to the research organization on a voluntary basis.

In the Russian Federation, statistics data on the indicator is not collected. In this connection, IRNITU (TL-ISTU) Transport Laboratory has started a systematic collection of data in the form of GLONASS / GPS tracks, including urban and suburban bus routes [1,2].

With respect to the assessment of the reliability of the urban highway network operation, a simplified methodology has been proposed. The Time Index is considered as the ratio of the time spent to pass a URN section during peak hours to the duration of running under free vehicular flow conditions.

$$
T I=\frac{T_{P}}{T_{F F}},
$$


where $T_{P}$ is the time spent to pass a urban highway network section during peak hours $(\min )$;

$T_{F F}$ - time spent to pass a section under free traffic flow conditions (min).

\section{Results}

To collect the necessary data in the city of Irkutsk, 57 urban highway network sections were selected, which differ in the number of lanes, the linear density of the location of traffic lights, unregulated intersections and pedestrian crossings, and street junctions. The turget of processing each track was to obtain the following characteristics: its length $(\mathrm{km})$ and duration ( $\mathrm{min}$ ); duration of running time (when the speed exceeds $5 \mathrm{~km} / \mathrm{h}$ ); duration of stops (when the speed is less than $5 \mathrm{~km} / \mathrm{h}$ ); maximum, minimum and average speed. In order to cover the wide range of traffic conditions, the track record was made for each of the sections at a specified time of the day: 08:00-09:00 in the morning; 13:00-14:00 in the afternoon; 17:00-18:00 in the evening (the central part of the city) and 18:00-19:00 in the evening (the peripheral areas of the city); and 23:00 - 24:00 at night.

According to the data that is proposed to be collected for each urban highway network section (segment), the Time Index is defined as the ratio of the travel time of the worst of four tracks to the travel time of the best track. Such definition has been proposed for cases where there is not any mass statistics data. In the case of accumulation of mass data, the Time Index can be determined in accordance with formula (1).

The operation reliabity of urban highway network sections has been formed on the basis of the quantiles of the distribution of the obtained values of the Time Index. It has been proposed to assess the reliability of operation of sections of urban streets and roads (segment length is up to $2 \mathrm{~km}$ ) in accordance with Table. 2.

Table 2. Assessment of Traffic Conditions in the Segments of urban road network.

\begin{tabular}{|c|c|c|}
\hline $\begin{array}{c}\text { Service } \\
\text { Level }\end{array}$ & $\begin{array}{l}\text { TI, Time Index } \\
\text { Value }\end{array}$ & Operation Conditions \\
\hline A & $<1,2$ & $\begin{array}{c}\text { No deterioration in traffic conditions is observed during } \\
\text { peak hours }\end{array}$ \\
\hline B & $1,2-1,3$ & $\begin{array}{c}\text { Slight deterioration in traffic conditions is observed } \\
\text { during peak hours }\end{array}$ \\
\hline $\mathrm{C}$ & $1,3-1,5$ & $\begin{array}{c}\text { Deterioration in traffic conditions is observed during peak } \\
\text { hours }\end{array}$ \\
\hline $\mathrm{D}$ & $1,5-2$ & $\begin{array}{c}\begin{array}{c}\text { Significant deterioration in traffic conditions is observed } \\
\text { during peak hours }\end{array} \\
\end{array}$ \\
\hline $\mathrm{E}$ & $>2$ & $\begin{array}{l}\text { Poor reliability of the segment during peak hours. Traffic } \\
\text { congestions are possible. }\end{array}$ \\
\hline
\end{tabular}

To conduct comparative analysis of the urban road network operational reliability in various cities or various areas as parts of a city, it is proposed to determine the weighted value $T I$

$$
T I=\frac{\sum_{i=1}^{i=n}\left(v_{i} l_{i}\right)}{\sum_{i=1}^{i=n} v_{i} l_{i}},
$$

where $T I_{i}$ is the value of the Time Index in segment $i$;

$v_{i}$ is traffic volume in the segment in the considered direction (vehicle/h);

$l_{i}$ - the length of the segment $i(\mathrm{~km})$; 
$n$ - the number of segments.

\section{Conclusion}

The presented results are considered as preliminary because German authors have shown that the LOS scale based on the Travel Time Index should take into account the length of the trips [4]. Thus the research group of IRNITU Transport Laboratory plans to collect data in order to clarify the Time Index scoring for the urban road networks, as well as to develop the assessment of the reliability of public passenger transport routes.

Within the framework of the project "Development of Scientific-based Proposals on the Russian Federation Traffic Management Quality and Efficiency Assessment System", the research group of IRNITU (TL-ISTU) Transport Laboratory performed the development of a method to assess the reliability of the urban road networks functioning. Alternative criteria were considered. Travel Time Index was suggested to be used to assess the reliability of operation of the urban road networks.

\section{References}

1. O. Lebedeva, A. Mikhailov, Model of Passenger Counting System Data Treatment. 12th International Conference "Organization and Traffic Safety Management in large cities", SPbOTSIC-2016, 28-30 September 2016, St. Petersburg, Russia Transportation Research Procedia, 20, pp. 401 - 405 (2017)

2. A. Levashev, A. Mikhailov, I. Golovnykh, Modelling parking based trips. Proceedings of the VIII-th international conference on «the Sustainable City VIII», WIT Press, UK, 2, pp. $1067-1076$ (2013)

3. A.G. Levashev, A.Yu. Mikhailov, M.I. Sharov, On the Issue of Assessing the Quality of Transport Services in Cities. Modern Problems of the Transport Complex in Russia, 3, pp.16-23 (2013)

4. A. Levashev, A. Mikhailov, M. Sharov, Irkursk transportation master plan solutions for the public transport system development . Proceedings of the international conference on «Energy Production and Management in the 21 st Century - The Quest for Sustainable Energy», WIT Press, UK, 1, pp. 651 - 660 (2014)

5. A. Levashev, Application of Geoinformation Technologies for the Transportation. 12th International Conference "Organization and Traffic Safety Management in large cities", SPbOTSIC-2016, 28-30 September 2016, St. Petersburg, Russia Transportation Research Procedia, 20, pp. 406 - 411 (2017)

6. A. Levashev, E. Prelovskaya, Modern Approach of Street Space Design. 12th International Conference "Organization and Traffic Safety Management in large cities", SPbOTSIC-2016, 28-30 September 2016, St. Petersburg, Russia Transportation Research Procedia, 20, pp. 523 - 528 (2017)

7. A.Yu. Mikhailov, A.G. Levashev, M.I. Sharov, Modern Methods to Assess the Quality of Traffic Management in Cities. Deposited manuscript, 64-B (2015)

8. M. Sharov, A. Levashev, A. Mikhailov, Assessment of development prospect of the electric public transportation system in Irkutsk. Proceedings of the International ETGCongress 2013 «Energiever-sorgung auf dem Weg nach 2050», VDE VERLAG GMBH, Berlin, Germany, 139, pp. 65 - 70 (2013)

9. M. Sharov, A. Mikhailov, Document Urban Transport System Reliability Indicators. 12th International Conference "Organization and Traffic Safety Management in large 
cities", SPbOTSIC-2016, 28-30 September 2016, St. Petersburg, Russia Transportation Research Procedia, 20, pp. 591 - 595 (2017)

10. N. Cohn, TomTom Traffic Index: Toward a Global Measure. ITS Conference, France, Paris, 9 p. (2014)

11. B. Friedrich, M. Friedrich, A. Bennecke, J. Lohmiller, Time-dependent service quality of network sections; 6th International Symposium on Highway Capacity and Quality of Service, ISHC Stockholm (2011)

12. Estimating urban traffic and congestion cost trends for Australian cities//Working Paper 71. Bureau of Transport and Regional Economics. Department of Transport and Regional Services, Canberra, Australia, 161 p. (2007)

13. https://www.gov.uk/government/collections/road-congestion-and-reliability-statistics\# publications (2017)

14. Managing urban traffic congestion//OECD Publications, 294 p. (2007)

15. D.P. Racca, D.T. Brown, Study and Calculation of Travel Time Reliability Measures. Center for Applied Demography \& Survey Research, University of Delaware, 64 p. (2012)

16. S. Susilawati, M. Taylor, Travel Time Reliability Measurement for Selected Corridors in the Adelaide Metropolitan. http://www.easts.info/publications/ journal_proceedings/journal2010/ 100398.pdf.

17. M. Fadaei, O. Cats, Evaluating the impacts and benefits of public transport design and operational measures, Transport Policy, 48, pp. 105-116 (2016)

18. L. Kieu, A. Bhaskar, E. Chung, Public transport travel-time variability definitions and monitoring, Journal of Transportation Engineering, 141, no. 1. (2015) 